УДК 342.951:351.82

DOI https://doi.org/10.32849/2663-5313/2020.7.28

олена Недайхліб,

аспірантка кафедри міжнародного, європейського екологічного права

та иивільно-правових дисииплін

Навчально-наукового інституту права

Сумського державного університету,

головний судовий експерт

Сумського науково-дослідного експертно-криміналістичного иентру

Міністерства внутрішніх справ Украӥни

\title{
ПРАВОВИЙ ЗМІСТ СТАНДАРТИЗАЦІЇ ПРОФЕСІЙНОЇ ДІЯЛЬНОСТІ В ПОХОРОННІЙ СПРАВІ
}

Проблема кадрового забезпечення у сфері послуг завжди залишалася гострою у зв'язку з людино-орієнтованою специфікою такої діяльності. У похоронній справі як одній із найбільш соиіально вразливих галузей питання підготовки кваліфікованих кадрів стоїть чи не найгостріше. 32017 року в Украӥні розпочалася робота з підготовки бази для створення нової начіональної кваліфікачійної системи, пов'язаної з впровадженням міжнародних систем професійних стандартів. Приниипово нові державні професійні стандарти, що є необхідними як для реальних $і$ потенційнх працівників, так і для роботодавців, визначатимуть вимоги до рівня знань і компетентності працівника в певній професійній сфері.

Аналіз нормативно-правових засад похоронної справи в Україні свідчить, що до професійного рівня працівників сфери ритуального обслуговування висуваються низькі кваліфікаційні вимоги, національні освітньо-кваліфікачійні програми підготовки або курси підготовки таких фахівців галузі відсутні. Водночас світовий досвід чітко вказує на необхідність затвердити й застосувати обов'язкові професійні стандарти як один із найефективніших засобів контролю якості в похоронному бізнесі. Вимоги європейського стандарту галузі поховання до професіоналізму персоналу не передбачають отримання виключно академічних знань, проте наявність певних компетениій може бути підтверджено відомостями щодо набутого досвіду в похоронній галузі. Водночас суттєвим критерієм та організачійно-правовою умовою підтвердження підготовки фахівия похоронної галузі має залишатися документ (диплом) про підготовку, визнаний акредитованим органом влади з відповідних питань та/або національною чи світовою спілкою-асоціацією спеціалістів похоронної справи.

Впровадження професійних стандартів прачівників сфери ритуальних послуг дасть змогу вивести на якісно новий рівень відносини суб'єктів галузі поховання, систему професійної освіти, шо зі свого боку сприятиме зростанню якості послуг, робіт та продукції. Крім того, професійні стандарти допоможуть усунути невідповідність між знаннями навчальних закладів $і$ вимогами роботодавиів, оскільки вони стануть основою для розроблення єдиних освітніх стандартів.

Ключові слова: соціономічна сфера, поховання, похоронна справа, професійна підготовка, кваліфікація.

Постановка проблеми. Актуальним завданням є підвищення ефективності професійної освіти для представників соціономічних професій, де об'єктом праці є людина 3 ï̈ різноманітними проблемами і труднощами. Похоронна справа як сфера примусового споживання вимагає створення належних умов реалізації потреб, прав і законних інтересів індивіда, забезпечення яких неможливо досягти без професійних стандартів і підготовки кваліфікованих фахівців. Світова індустрія похоронного обслуговування населення висуває високі вимоги до професіоналізму персоналу. Сучасною соціальною практикою сфери ритуальних послуг затребуваний креативний, самостійний, ініціативний, відповідальний фахівець похоронної справи, який спроможний професійно будувати свої взаємини з уразливими людьми та адекватно оцінювати себе як професіонала, а також готовий до подальшої самоосвіти та самореалізації як суб'єкта професійної діяльності, тобто до постійного професійного розвитку. На жаль, нормативноправові засади похоронної справи в Україні містять вкрай мало вимог до професійного рівня працівників сфери ритуального обслуговування та взагалі не передбачають наці- 
ональних освітньо-кваліфікаційних програм підготовки або курсів підготовки таких фахівців галузі. Відповідно до цього, одним із важливих завдань реформування галузі поховання є визначення критеріїв, організаційно-правових засад і вимог до підготовки такого фахівця.

Аналіз останніх досліджень і публікацій. Науково-теоретичне розроблення проблематики регулювання похоронної справи як соціально значущої сфери послуг здійснювали А.О. Гунда, С.М. Мойсеєва, I.I. Руда, I.C. Похиленко, П.С. Уланов. Дослідниками нагромаджено багатий досвід щодо трактування суті соціономічних професій (Л.В. Буркова, О. Ліпман, Є.О. Клімов, Н.Л. Рабецька та інші) та вивчення теоретичних засад і здійснення практичних підходів до здійснення професійного розвитку фахівців (Н.Л. Кучеренко, Л.М. Прудка, I.О. Носова, О.О. Приймук та інші). Проте встановлено, що українськими науковцями та вченими не досить висвітлено проблему забезпечення системного професійного розвитку фахівців похоронної справи як надавачів споживчих послуг соціономічної сфери, а в науковій адміністративно-правовій літературі проблема підготовки фахівців у галузі поховання та розроблення освітньо-кваліфікаційних стандартів узагалі не досліджена і потребує грунтовного аналізу.

Метою статті $є$ обгрунтування необхідності підготовки кваліфікованих спеціалістів у сфері похоронної справи та ритуальних послуг, які мають володіти навичками та вміннями професійного спілкування з уразливими споживачами соціономічної сфери поховання, забезпечувати дотримання світових стандартів із метою підтримки захисту прав людини в афективній сфері поховання та сталого розвитку національної похоронної галузі.

Виклад основного матеріалу. До типу соціономічних належать професії, у яких предметом праці виступає інша людина чи група людей, основними виробничими завданнями працівника $є$ безпосередній вплив на інших людей (навчання, виховання, лікування й догляд, інформаційне й соціально-побутове обслуговування), успішність професійної діяльності значною мірою залежить від умінь працівника встановлювати безпосередні соціальні контакти через вербальні (мовлення) і невербальні (міміка, жести, виразні рухи) засоби спілкування. Таким ознакам відповідають професії вчителя, лікаря, психолога, соціального працівника, журналіста, соціолога, юриста, надавача ритуальних послуг тощо. Отже, особливість професійної діяльності представників соціономічних професій полягає в тому, що в іiі основі лежить взаємодія з іншими людьми, що спрямована на надання їм певної допомоги у розв'язанні складних життєвих ситуацій [9, с. 21].

Людина за життя може не вступати у шлюбні або трудові відносини, не мати у власності землі чи житла, а також жодного разу не скористатись у процесі життєдіяльності Лісовим, Водним чи Митним кодексами. Єдині юридично значущі факти за життя кожного - це народження і смерть. Якщо допомога фахівця під час появи на світ (раніше - повитухи, тепер - акушера) $€$ звичним і поширеним явищем, то послуги 3 похорону (не ритуалу) в Україні, наприклад, й досі надаються суб'єктами без відповідної освіти.

У Класифікаторі професій ДК 003:2010 України за сферою діяльності «Ритуальні послуги» визнано професії базової професійної назви $5143 \ll$ «тримувачі похоронних контор, трунарі та бальзамувальники» (усі категорії спеціальностей) та 5149 «Інші працівники, пов'язані з наданням послуг окремим особам» (за спеціальністю «Організатор ритуалу») [3].

Варто зазначити, що більшість професій, вміщених до розділу вимог до працівників сфери торгівлі та послуг Класифікатора професій, вимагає повної загальної середньої та професійно-технічної освіти чи повної загальної середньої освіти та професійної підготовки на виробництві, тобто не потребують вищої освіти чи грунтовного досвіду роботи.

Унаслідок цього, можливо, перелік кваліфікаційних характеристик працівників похоронної справи як сфери побутових послуг, крім положень керівних посад директора чи завідувача крематорію, кладовища, похоронної контори й колумбарію, у кваліфікаційних вимогах до працівників передбачає наявність лише загальної середньої освіти з професійною підготовкою на виробництві, без вимог до стажу роботи. Кваліфікаційні вимоги до вказаних вище керівних посад об'єктів ритуального призначення щодо вищої освіти відповідного напряму підготовки, за умови відсутності освітніх напрямів підготовки фахівців похоронної справи в Україні, також викликають подив.

Розглянемо детальніше коло завдань ритуальної служби. Правове регулювання надання ритуальних послуг регламентоване Законом України «Про поховання та похоронну справу» (далі - Закон), відповідно до ст. 2 якого під ритуальними розуміються послуги, пов'язані з організацією поховання та облаштуванням місця поховання [8]. За 
національним класифікатором України ДК 009:2010 «Класифікація видів економічної діяльності», організування поховань і надання суміжних послуг передбачає: поховання та кремацію трупів людей або тварин (підготовку тіла для поховання або кремації, бальзамування та надання інших похоронних послуг, поховання або кремацію, оренду обладнаного місця в ритуальних залах), оренду або продаж місць на цвинтарі, догляд за могилами та мавзолеями [4].

Водночас повне визначення складу послуг із поховання та постачання ритуальних товарів, замість спеціального згаданого вище Закону, міститься в положеннях ст. 197 Податкового кодексу України (п.п. 197.1.10) [6], до переліку яких віднесено:

а) виклик агента ритуальної служби для оформлення замовлення на організацію та проведення поховання;

б) оформлення медичної довідки про причини смерті;

в) доставлення замовникові ритуальних атрибутів для організації поховання;

г) навантаження, розвантаження та перенесення ритуальних атрибутів;

г) транспортні послуги, що надаються у процесі організації поховання;

д) продаж стандартної труни;

е) продаж контейнера для перевезення оцинкованої труни; запаювання оцинкованої труни;

є) утримання тіл померлих у холодильних камерах понад норму перебування (після смерті у лікувальному закладі, а також тих, які померли вдома чи інших місцях);

ж) послуги з підготовки тіла покійного до поховання або кремації (послуги перукаря та косметолога, обмивання, бальзамування, укладання в труну);

3) копання могили;

и) перенесення труни з тілом покійного (додому, до квартири в багатоповерховому будинку, до моргу; з дому, квартири, моргу тощо до місця поховання);

i) музичний супровід обряду поховання;

i) проведення громадянської панахиди;

й) послуги організатора обряду поховання;

к) виготовлення та встановлення металевої намогильної таблички, хреста, надголовника або тимчасового пам'ятного знака;

л) продаж стандартних похоронних вінків і траурних стрічок для них;

м) організація відправлення труни 3 тілом покійного чи урни 3 прахом покійного за кордон;

н) у разі проведення підпоховання в могилу - послуги з демонтажу елементів наявного надгробка (пам'ятника) та їх установлення; о) написання тексту на траурній стрічці;

п) кремація;

р) продаж урни;

с) продаж кубка для урни;

т) поховання урни 3 прахом у могилу, у колумбарії, розвіювання праху.

Отже, видно, що характерною рисою похоронної справи є її неоднорідність і різноплановість. Крім того, комерційний і некомерційний складники ритуальної діяльності в тій чи іншій формі є об'єктами регулювання публічної адміністрації (державного, муніципального рівня). Прийняття замовлення й укладення договору про організацію похорону, супровід зберігання померлих і робота 3 підготовки до похорону, транспортування померлих та їхніх близьких, експлуатація територій, будівель і споруд, іноді - із будівництвом останніх, консультаційно-інформаційна діяльність із значним психоемоційним навантаженням, торгово-закупівельна діяльність, похоронне мистецтво та обрядовість, ритуальне та похоронне страхування, меморіальна і дослідницька діяльність поряд із притаманною будь-якому суб'єкту господарювання адміністративно-господарською діяльністю з представництвом інтересів підприємств в органах влади та громадських організаціях - це розмаїття завдань вимагає всебічної грунтовної підготовки фахівця похоронної справи, що нині значною мірою не реалізовано.

В умовах євроінтеграції України спостерігається налагодження нових міжнародних зв'язків і здійснюється широкий обмін досвідом у різних галузях, тому постає питання професійної підготовки спеціалістів ритуальної сфери із запровадженням нових професійних стандартів галузі похоронної справи.

Професійний стандарт - це затверджені в установленому порядку вимоги до кваліфікації працівників, їхньої компетентності, що визначаються роботодавцями та слугують основою для формування професійних кваліфікацій.

Загальні вимоги до розроблення професійних стандартів в Україні визначено Методикою розроблення професійних стандартів, затвердженою Наказом Міністерства соціальної політики України від 22 січня 2018 р. № 74 [5], з метою методичної допомоги роботодавцям, їхнім організаціям та об'єднанням, галузевим (міжгалузевим) радам, центральним органам виконавчої влади, науковим установам, іншим заінтересованим суб'єктам у забезпеченні єдиного підходу та дотриманні об'єктивності під час розроблення професійних стандартів і забезпечення якості проведення їх перевірки. Роз- 
роблення професійного стандарту запроваджується залежно від потреби роботодавців у кваліфікованій робочій силі, ії розподілу за робочими місцями (посадами), форм зайнятості та умов праці для окремої професії, за якою присвоюється повна кваліфікація, або для групи споріднених професій (професійних назв робіт, посад) у певній сфері професійної діяльності, або для окремих (однієї чи кількох) трудових функцій, за якими присвоюються часткові кваліфікації. Порядок розроблення та затвердження професійних стандартів, затверджений Постановою Кабінету Міністрів України від 31 травня 2017 р. № 373, встановлює загальні вимоги до процедури розроблення, громадського обговорення, затвердження, введення в дію та перегляду професійних стандартів [7].

Слід зауважити, що за вказаною вище Методикою одним із принципів розроблення професійних стандартів є врахування успішного міжнародного досвіду країн. У розвинених країнах, таких як США, Великобританія, Японія та інших, трудові дії працівників, разом із відповідними вимогами до знань, умінь, навичок, уже давно проаналізовані, структуровані й викладені в компактній стандартній формі та успішно застосовуються як роботодавцями, так і закладами освіти, організаціями 3 профорієнтації громадян тощо.

У галузі похоронної справи країн Свропи, наприклад, стандартом похоронної галузі EN 15017: 2019 «Funeral Services - Requirements» [2] регламентовано, що всі особи, що займаються похоронними послугами, повинні мати належну підготовку для виконання завдання. Освітні вимоги виділено окремо для похоронного директора (розділ 5.2) і персоналу похоронної служби (розділ 5.3). Підготовку поділено на теоретичний i практичний блоки, проходження яких має підтверджуватись дипломом. Прикметно, що диплом має бути державного зразка, тобто визнаний відповідним національним органом державної влади або національної похоронної організації. Недержавна кваліфікація є неприйнятною, оскільки не забезпечить проведення незалежної оцінки. Для отримання цього диплома всі студенти мають скласти річний тест за результатами підготовки (тренінгу): не менш ніж 100 годин для похоронного директора і 50 годин - для персоналу ритуальної служби. Цю підготовку має бути пройдено протягом перших двох років із дня отримання посади. Наступною обов'язковою умовою є адекватна подальша освіта в сумі 20 годин протягом п'яти років. Прикметно, що підготовку дозволяється виконати частково завдяки навчанню на робочому місці.
Кредити інших годин можуть бути зараховані в результаті отримання академічного ступеня або шляхом врахування попереднього практичного досвіду роботи в галузі поховання

Підготовка фахівця похоронної справи повинна передбачати вивчення: 1) державноправової регламентації галузі та розподілу повноважень органів публічної адміністрації; законодавства та юрисдикції; 2) основ економіки та менеджменту, включно з управлінням якістю; 3) основ санітарної науки, зокрема гігієнічної обробки померлих, гігієнічних вимог та обмеження для персоналу і матеріалу; 4) психології скорботи і трауру, консультування; 5) поховальної культури і ритуалів; 6) технічних стандартів і регламентів похорону, кремації і кладовища; 7) вимог і заходів забезпечення охорони довкілля, охорони здоров'я та безпеки.

Навчання може бути загальним за всіма напрямами або поділеним на спеціалізовані етапи підготовки, що фокусуються на окремих аспектах похоронного бізнесу; може бути організовано як модульне або як подвійна система в освітньому закладі і в компанії. Докладні навчальні програми зазначено в стандарті EN 15017: 2019, в додатку А [2].

Треба наголосити, що стандартом EN 15017: 2019 передбачено обов'язок власника (-ів) або керівництва ритуальної служби гарантувати підготовку персоналу, що весь похоронний персонал має навички та досвід поводження з померлими особами та надання допомоги їхнім родичами. Один із керівників ритуальної служби призначається супервайзером (відповідальним за навчання). Окремою загальною вимогою професійного стандарту передбачено таке: весь похоронний персонал має поводитися шанобливо; весь похоронний персонал повинен дотримуватися відповідного дрескоду і проявляти належну повагу до соціальних, релігійних і культурних вірувань померлого і клієнта.

У контексті реалізації концепції навчання впродовж життя дедалі більшу популярність набуває твердження про те, що немає значення, в який спосіб і де людина отримала свої навички, якщо тільки вона може довести їх наявність. Як бачимо, положення стандарту EN 15017: 2019 відповідають поняттю «кваліфікація» (qualification), наведеному в Європейській рамці кваліфікацій для навчання впродовж життя (The European Qualifications Frameworks for Lifelong Learning - EQF), що тлумачиться як «офіційний результат процедур оцінки й офіційного визнання, що присвоюється рішенням уповноваженого органу про досягнення 
особою (особистістю) результатів навчання відповідно до визначених стандартів» [1]. Визначення СРК передбачає, що кваліфікація базується на вимогах певного стандарту, в якому йдеться про результати навчання У цьому визначенні передбачається процедура оцінки й офіційного визнання як основа для проведення сертифікації уповноваженим органом.

Отже, належна професійна підготовка та наявність професійних стандартів забезпечують високий рівень володіння сучасними знаннями фахівцями похоронної справи Європи, належну якість надання послуг, постійне підвищення рівня професійних знань, навичок і вмінь, створення гнучкої системи управління відповідно до розвитку науково-технічного прогресу, а також створення умов кваліфікаційного розвитку працівників, заохочення в підвищенні своєї кваліфікації.

Недосконалість вітчизняного нормативно-правового регулювання організації ритуальної діяльності в частині відсутності необхідних регламентів і процедур підготовки, професійних і кваліфікаційних вимог до кадрів заважає також налагодженню системи відносин із зовнішніми організаціями (професійними організаціями, органами влади, спеціалізованими вищими навчальними закладами). Крім створення умов для професійної підготовки кадрів для ритуальних служб, на базі закладів вищої освіти можливо організовувати курси підвищення кваліфікації, проведення семінарів, конференцій, конкурсів і виставок, присвячених питанням похоронної справи, а також проводити дослідження та розроблення у співробітництві зі спеціалізованими підприємствами, створювати спеціалізовані друковані видання для учасників ринку, вступати до професійних асоціацій національного та світового рівнів.

\section{Висновки}

Упродовж останніх років у світі розвиваються процеси стандартизації професійної діяльності, супроводжуючись методиками розроблення професійних та освітніх стандартів. Розроблення державних стандартів професій галузі поховання в Україні вимагає впровадження стандартів академічної освіти та підтвердження практичного досвіду під час підготовки фахівців галузі, на противагу наявним превалюючим кваліфікаційним вимогам до таких працівників щодо середньої освіти без стажу роботи. 3 метою розвитку вітчизняної сфери похоронної справи необхідно забезпечити галузь компетентними фахівцями з відповідною динамічною комбінацією знань, умінь і практичних навичок, способів мислення, професійних, світоглядних і громадянських якостей, моральноетичних цінностей, що визначає здатність особи успішно здійснювати професійну та подальшу навчальну діяльність і є, як правило, результатом навчання на певному рівні вищої освіти. Аналіз нормативних документів, методичних джерел, аналітичних матеріалів стандартизації професійної діяльності в галузі ритуальних послуг Європи засвідчує необхідність вироблення єдиних підходів до стандартизації професійної підготовки, що стане основою як для конструктивної переорієнтації змісту професійної освіти, так і забезпечить компетентісний підхід у похоронній справі, у контексті підтримки адміністративних реформ системи кваліфікацій та галузі поховання в Україні.

\section{Список використаних джерел:}

1. The European Qualifications framework for lifelong learning: descriptors defining levels in The European Qualifications framework (EQF). URL: http://ec.europa.eu/dgs/education_culture.

2. The European Standard EN 15017: 2019 'Funeral Services - Requirements' published by CEN in 2005, approved by CEN on 28 July 2019. URL: https://www.en-standard.eu/bs-en15017-2019-funeral-services-requirements.

3. Класифікатор професій ДК 003:2010 : Наказ Держспоживстандарту України від 28 липня 2010 p. № 327. URL: https://zakon.rada.gov.ua/ rada/show/va327609-10\#Text.

4. Класифікація видів економічної діяльності ДК 009:2010 : Наказ Державного комітету України $з$ питань технічного регулювання та споживчої політики від 11 жовтня 2010 р. № 457. URL: http://kved.ukrstat.gov.ua/KVED2010/96/KVED $10 \quad 96$ 03.html.

5. Методика розроблення професійних стандартів : Наказ Міністерства соціальної політики України від 22 січня 2018 р. № 74. URL: https:// zakon.rada.gov.ua/laws/show/z0165-18\#Text.

6. Податковий кодекс України : Закон України від 2 грудня 2010 р. № 2755-VI. URL: https://zakon.rada.gov.ua/laws/show/2755-17.

7. Порядок розроблення тазатвердження професійних стандартів : Постанова Кабінету Міністрів України від 31 травня 2017 р. № 373. URL: https://zakon.rada.gov.ua/laws/show/373-2017$\% \mathrm{D} 0 \% \mathrm{BF} \# \mathrm{n} 11$.

8. Про поховання та похоронну справу : Закон України від 10 липня 2003 р. № 1102-IV. URL: http://zakon3.rada.gov.ua/laws/show/1102-15.

9. Рабецька Н.Л. Формування комунікативної компетентності майбутніх фахівців соціономічної сфери у професійній підготовці : дис. ... канд. пед. наук : 13.00.04 / Південноукраїнський національний педагогічний університет імені К.Д. Ушинського. Одеса, 2018. 299 с. 
Olena Nedaikhlib. Legal content of standardization of professional activity in funeral business

The problem of staffing in the service sector has always been acute in connection with the person-oriented specifics of such activity. In the funeral business, as one of the most socially vulnerable areas, the training of qualified personnel is one of the most acute. Since 2017, the work on the preparation of the base for the creation of a new national qualifying system related to the introduction of international systems of professional activity standards began in Ukraine. Fundamentally new state professional standards, which are necessary as for both real and prospective personal, so and for employees, will determine the requirements to the level of knowledge and competence of the employee in a certain professional sphere.

The analysis of the legal principles of the funeral service industry in Ukraine shows that the professional level of workers in the field of ritual service are under the low qualification requirements. The National Educational qualification programs or courses of training of such funeral specialists are absent. At the same time, the world experience clearly indicates the need to approve and apply mandatory professional activity standards as one of the most effective quality assurance tools in the funeral business. The requirements European the standard of the burial area for staff professionalism do not imply obtaining only academic knowledge, but the presence of certain competencies can be confirmed by information on the experience gained in the funeral sector. At the same time, an essential criterion and legal requirement for confirmation of education of a funeral industry's specialist should remain a document (diploma) on training, recognized by the accredited national state authority on relevant issues and/or national or world association-organization of funeral specialists.

The implementation of professional activity standards in the funeral service industry in Ukraine will bring to a qualitatively new level of relations of subjects of burial, system of professional education, which in turn will contribute to the growth of service, work and products quality. Additionally professional standards will help to eliminate the discrepancy between the knowledge of educational institutions and the requirements of employers, as they will become the basis for developing uniform educational standards.

Key words: socionomic sphere, burial, burial case, professional training, qualification. 